\title{
Energy crops and renewable energy: overall and process efficiency
}

\author{
Winfried Schäfer ${ }^{1)}$ \\ ${ }^{1)}$ MTT (Maa-ja elintarviketalouden tutkimuskeskus), Kotieläintuotannon tutkimus, Vakolantie 55, 03400 \\ Vihti,winfried.schafer@mtt.fi
}

\section{Summary}

\section{Introduction and Objectives}

The crop scientist focuses his research on high quantity and quality of yield based on a sustainable tilth. The engineer is interested in maximisation of the process efficiency. He interprets the crop scientist's approach as maximisation of photosynthesis efficiency. Objective of this paper is to support the assessment of energy crop production applying engineering sciences methods in energy accounting.

\section{Methods and results}

The sustainability of energy crop production is assessed by calculating the overall efficiency using rape as example. The results show that the high process energy efficiency of the rapeseed cultivation fosters common acceptance of rape as energy crop. Even under Finnish climate conditions, exergy of rape crop exceeds up to 11-times the energy input for production and exergy of seed up to 3.7 times. Conversion of rapeseed into fuel decreases the energy surplus. Rape methyl ester (RME) delivers still 1.2-fold the energy input for cultivation and conversion. The whole rape crop (root, straw, seed) contains 3 to $6 \%$ of the overall energy input, RME 1 to $2 \%$ only. Animal production converts rape meal feed into manure, which is suitable for anaerobic digestion together with glycerine. The biogas augments the overall efficiency additionally 0.2 to $0.5 \%$. Rape cultivation requires a 4 to 7 -year crop rotation. This and the low overall efficiency make it difficult in Finland to achieve energy self-sufficiency replacing diesel fuel by RME. The technical efficiency of the photosynthesis limits the maximum energy yield and reaches up to $0.8 \%$ in Finland. By comparison, the efficiency of a photovoltaic collector is 165 to 248 -fold better than the conversion efficiency of biomass or biogas produced from rapeseed and rape straw into electric power. The efficiency of the thermal collector exceeds heat production from burning the rape crop 157 to 443 -fold. However, storage and continuous production of power and heat from sun energy is very limited. For that reason, the storage of sun energy in liquid carbon hydrates is subject of present research.

\section{Conclusion}

Energy crop production is captivating with many win-win situations: environmentally neutral bio-fuels replace polluting fossil fuels, farmers get better prices for energy crops, the agrochemical industry gains from intensification of energy crop production, and turn over of power industry grows due to increasing energy consumption to produce agrochemicals and to process biomass into fuel. As a following, the state tax income improves too. However, better prices for mainstream energy crops may trigger export of environmental pollution at the expense of food production because higher overall efficiency in tropical countries favours the import of organic raw material for bio fuel production. Yet, high process efficiencies of technical processes to convert biomass into fuel justify the production of renewable energy from organic waste and residues. Thus, agriculture should not focus on energy crop production but produce high quality food environment-friendly. The overall efficiency of energy production from energy crops will never be competitive with solar techniques. Solar collectors replace fossil fuels for heat production outside agriculture already now sustainable and more efficient. Research on solar-technical processes to produce liquid carbon hydrates from methane, carbon dioxide, and water powered by solar energy without diversion into photosynthesis offers much a greater potential than research on energy crop production. As a measure for sustainability of renewable energy production, the energy surplus from sun energy conversion per capita and square meter is proposed.

\section{Key words}

Energy crops, renewable energy, efficiency, rape methyl ester 


\section{Introduction and Objectives}

Agricultural machinery and buildings cause up to $40 \%$ of production cost. The high costs of technical input forces to specialisation of farm production by splitting animal and crop production located at different areas or even continents, narrow crop rotations, and dependency from fossil fuels and counteracts to sustainable farming principles and green house gas mitigation. In short, the entropy of modern farming systems increases. However, a physical and technological approach and engineering proficiency may contribute to the aims of sustainable farming also in respect of energy crop issues.

The crop scientist focuses his research on high quantity and quality of yield based on a sustainable tilth. The engineer is interested in maximisation of the process efficiency. He interprets the crop scientist's approach as maximisation of photosynthesis' efficiency. Odum (1996) developed an excellent logical framework for energy accounting based on sun energy input. Although the methodology is further developed and applied worldwide (e.g. Bastianoni et al. 2007, Jiang et al. 2007, Rótolo et al. 2007, Ukidwe \& Bakshi 2007), the methodology seems to be quite unknown to European decision makers in the field of environmental and agricultural sciences. One reason may be that applied thermodynamics in environmental accounting requires more scientific skills than life cycle analysis (ISO 14040) which is easily to accomplish by simple spreadsheet calculations. Objective of this paper is to support the assessment of energy crop production in terms of sustainability and energy efficiency applying basic engineering sciences methods in energy accounting. Figure 1 shows the theoretical approach.

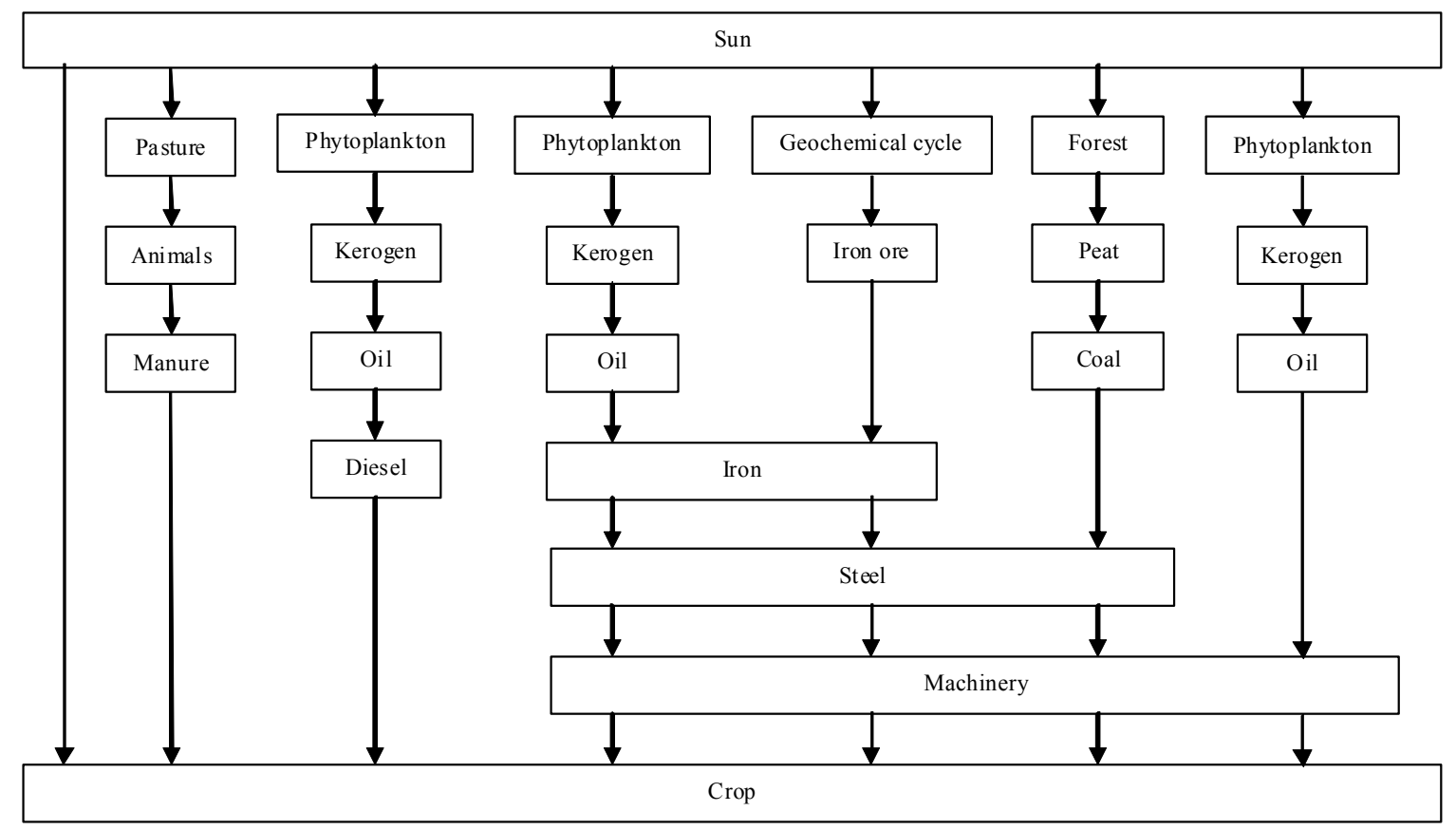

Figure 1: Simplified model of energy crop production. The model shows all the exergy flows directly or indirectly needed for the process and the partial efficiencies of the backward steps to the original solar exergy source. (Bastianoni et al. 2007, modified).

\section{Material and methods}

The engineer quantifies the sustainability of energy crop production by means of the overall efficiency $\eta_{\mathrm{O}}$ that is the energy output divided by the energy input of all processes involved:

$$
\eta_{\mathrm{O}}=\left(\sum_{\mathrm{i}=1}^{\mathrm{n}}\left(\mathrm{A}_{\mathrm{i}} \cdot \mathrm{S}_{\mathrm{i}} \cdot \eta_{\mathrm{i}}\right)\right) \cdot\left(\sum_{\mathrm{i}=1}^{\mathrm{n}}\left[\mathrm{A}_{\mathrm{i}} \cdot\left(\mathrm{S}_{\mathrm{i}}+\mathrm{P}_{\mathrm{i}}+\mathrm{K}_{\mathrm{i}}\right)\right]\right)^{-1}
$$

A denotes the area, $\mathrm{S}$ the solar energy, $\mathrm{P}$ the energy input of crop cultivation, $\mathrm{K}$ the energy input of fuel conversion, $\eta_{i}$ the technical efficiency of photosynthesis and $i$ the member of crop rotation. The crop scientist concerns for $\eta_{\mathrm{i}}$ and to some extent for $\mathrm{P}$ while $\mathrm{K}$ and $\mathrm{P}$ is of engineers and partially animal production scientist's interest. Please note that the global solar-radiation intensity is limited like the cultivation area too. The equation is applicable for farm level, national level, and worldwide. However, it does not 
take into consideration the energy saving potential of crop fibre for heat insulation.

The calculation of the process energy efficiency includes the process energy input and the free energy (exergy) before and after processing. The engineer considers photosynthesis, cultivation, and conversion each as process. E.g., the process efficiency of burning biomass for heat production depends only on incinerator efficiency and on energy input for transport of biomass and ash. Additional treatment like pelleting, extraction of oil, anaerobic digestion, ethanol fermentation etc. raises the energy input considerably. The production of ethanol from corn renders always a negative exergy balance due to the thermodynamic laws (Patzek 2004).

Crop processing generates usually different products. Some are suitable for energy production others for fibre production, human nutrition or animal feed. This fact causes a methodological problem, called allocation. The process energy for rape crop production may be allocated to seed, straw, and roots. The process energy input for extraction, refining, and esterification of rapeseed oil has to be split between rape methyl ester (RME), meal, and glycerine, the by-product of esterification of rape oil. Depending on the allocation method, the process energy balance may diverge in a wide range.

\section{Results and discussion}

Table 1 shows a chain of processes of rape production and processing, their efficiencies and the resulting cumulated overall efficiency derived from different sources (Elsayed et al. 2003, Bugge 2000, Schäfer 1996).

Table 1: Energy input, energy output, process efficiency and overall efficiency of rape production and rape processing in Finland.

\begin{tabular}{|c|c|c|c|c|c|c|}
\hline Process & $\begin{array}{r}\text { Inp } \\
\text { kWh m }\end{array}$ & & kW & ${ }^{u t} \mathrm{a}^{-1}$ & $\begin{array}{l}\text { Process- } \\
\text { efficiency } \\
\%\end{array}$ & $\begin{array}{c}\text { Overall } \\
\text { efficiency } \\
\%\end{array}$ \\
\hline $\begin{array}{l}\text { crop } \\
\text { cultivation }\end{array}$ & $\begin{array}{l}\text { direct } \\
\text { and } \\
\text { indirect energy }\end{array}$ & $0.3-0.8$ & \begin{tabular}{|l} 
root \\
straw \\
seed $^{\text {b) }}$
\end{tabular} & $3.3-6.3$ & $\begin{array}{l}262-366 \\
262-366 \\
262-366 \\
\end{array}$ & $787-1100$ \\
\hline $\begin{array}{l}\text { photo- } \\
\text { synthesis }\end{array}$ & sun light & 1000 & \begin{tabular}{|l|} 
root \\
straw \\
seed $^{\text {b) }}$
\end{tabular} & $\begin{array}{l}1.1-2.1 \\
1.1-2.1 \\
1.1-2.1\end{array}$ & $\begin{array}{l}0.11-0.21 \\
0.11-0.21 \\
0.11-0.21\end{array}$ & $0.33-0.63$ \\
\hline incineration & $\begin{array}{l}\text { straw } \\
\text { seed }\end{array}$ & $2.2-4.2$ & $\begin{array}{l}\text { calorific } \\
\text { heat }\end{array}$ & $1.76-3.78$ & $80-90$ & $0.18-0.38$ \\
\hline $\begin{array}{l}\text { oil and } \\
\text { meal } \\
\text { production }\end{array}$ & $\begin{array}{l}\text { seed } \\
\text { energy }\end{array}$ & $\begin{array}{c}1.1-2.1 \\
0.1\end{array}$ & $\begin{array}{l}\text { oil. } \\
\text { meal } \\
\text { total }\end{array}$ & $\begin{array}{c}0.64-1.21 \\
0.46-0.89 \\
1.1-2.1\end{array}$ & $\begin{array}{l}52.9-55.1^{\mathrm{c})} \\
38.7-40.3^{\mathrm{d})} \\
91.7-95.5^{\mathrm{e})}\end{array}$ & $\begin{array}{l}0.06-0.12^{()} \\
0.05-0.09^{d)} \\
0.11-0.21^{\mathrm{e})}\end{array}$ \\
\hline bio-refinery & $\begin{array}{l}\text { seed } \\
\text { energy }\end{array}$ & $\begin{array}{l}1.1-2.1 \\
0.1-0.2 \\
\end{array}$ & $\begin{array}{l}\text { RME } \\
\text { meal }\end{array}$ & $\begin{array}{l}0.64-1.21 \\
0.46-0.89\end{array}$ & $84.6-95.5^{\mathrm{e})}$ & $0.11-0.21^{\mathrm{e})}$ \\
\hline $\begin{array}{l}\text { milk } \\
\text { production }\end{array}$ & $\begin{array}{l}\text { meal } \\
\text { direct and } \\
\text { indirect energy }\end{array}$ & $\begin{array}{c}0.46-0.89 \\
0.2^{\mathrm{g})}\end{array}$ & $\begin{array}{l}\text { milk }^{\mathrm{h})} \\
\text { manure } \\
\text { heat, } \mathrm{CH}_{4} \\
\text { total }\end{array}$ & $\begin{array}{l}0.09-0.18 \\
0.16-0.31 \\
0.21-0.40\end{array}$ & $\begin{array}{l}14.1-16.5 \\
17.1-19.1 \\
22.6-25.2 \\
53.9-60.7\end{array}$ & $\begin{array}{l}0.01-0.02 \\
0.02-0.03 \\
0.02-0.04 \\
0.05-0.09\end{array}$ \\
\hline $\begin{array}{l}\text { anaerobic } \\
\text { digestion }\end{array}$ & $\begin{array}{l}\text { manure } \\
\text { heat and power }\end{array}$ & $\begin{array}{l}0.16-0.31 \\
0.03-0.15\end{array}$ & $\begin{array}{l}\text { biogasi) } \\
\text { effluent' }\end{array}$ & $\begin{array}{l}0.08-0.15 \\
0.08-0.15\end{array}$ & $\begin{array}{l}33.3-41.7 \\
33.3-41.7\end{array}$ & $\begin{array}{l}0.01-0.02 \\
0.01-0.02\end{array}$ \\
\hline $\begin{array}{l}\text { power } \\
\text { production }\end{array}$ & biogas & $0.08-0.15$ & $\begin{array}{l}\begin{array}{l}\text { power } \\
\text { heat }\end{array} \\
\end{array}$ & $\begin{array}{l}0.03-0.05 \\
0.05-0.10 \\
\end{array}$ & $\begin{array}{l}33.3 \\
66.7 \\
\end{array}$ & $\begin{array}{l}<0.01 \\
<0.01\end{array}$ \\
\hline $\begin{array}{l}\text { thermal } \\
\text { collector }\end{array}$ & $\begin{array}{l}\text { sun energy } \\
\text { manufacture }\end{array}$ & $\begin{array}{l}1000 \\
2.3^{\mathrm{i})}\end{array}$ & heat & $600-800$ & $60-80$ & $59.9-79.8$ \\
\hline $\begin{array}{l}\text { photovoltaic } \\
\text { collector }\end{array}$ & $\begin{array}{l}\text { sun energy } \\
\text { manufacture }\end{array}$ & $\begin{array}{c}1000 \\
6-11^{\mathrm{k})}\end{array}$ & power & $100-150$ & $10-15$ & $9.9-14.9$ \\
\hline
\end{tabular}

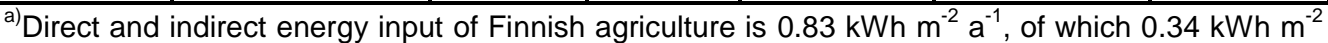
$\mathrm{a}^{-1}$ fossil fuels, of which 0.07 to $0.14 \mathrm{kWh} \mathrm{m}^{-2} \mathrm{a}^{-1}$ diesel/RME (LAMPINEN et al. 2006, NYHOLM et al. 2005, ELSAYED et al. 2003, BUGGE 2000, SCHÄFER et al. 1986). ${ }^{\text {b) }}$ Seed yield 160 to $310 \mathrm{~g}$ $\mathrm{m}^{-2}$; allocation of energy output: $1 / 3$ seed, straw, and root respectively. ${ }^{\mathrm{c})}$ In respect of oil. ${ }^{\mathrm{d}}$ In respect of meal. ${ }^{\text {e) }}$ In respect of oil/RME and meal. ${ }^{\text {f }}$ Oil extraction $416 \mathrm{Wh} \mathrm{kg}^{-1}$ seed; esterification $476 \mathrm{Wh} \mathrm{kg}^{-1}$ seed (CAMPA®- BIODIESEL GMBH \& CO. KG 2006, http://www.campa-

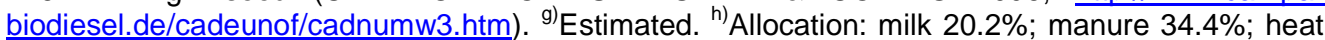

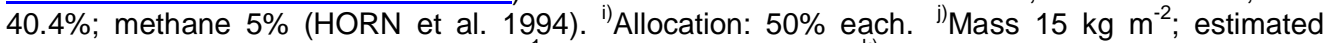
energy input for production $3.9 \mathrm{kWh} \mathrm{kg}^{-1}$; depreciation 25 years. ${ }^{\mathrm{k}} \mathrm{KNAPP}$ et al. 2000. 
The results show that the high process energy efficiency of the rapeseed cultivation fosters common acceptance of rape as energy crop. Even under Finnish climate conditions, exergy of rape crop exceeds up to 11-times the energy input for production and exergy of seed up to 3.7 times. Conversion of rapeseed into fuel decreases the energy surplus. Rape methyl ester (RME) delivers still 1.2-fold the energy input for cultivation and conversion. The whole rape crop (root, straw, seed) contains 3 to $6 \%$ of the overall energy input, RME 1 to $2 \%$ only. Animal production converts rape meal feed into manure, which is suitable for anaerobic digestion together with glycerine. The biogas augments the overall efficiency additionally 0.2 to $0.5 \%$. Rape cultivation requires a 4 to 7 -year crop rotation. This and the low overall efficiency make it difficult in Finland to achieve energy self-sufficiency on-farm replacing diesel fuel by RME.

The technical efficiency of the photosynthesis limits the maximum energy yield and reaches up to $5 \%$ of the insolation input in the tropics and up to $0.8 \%$ in Finland (Lampinen \& Jokinen 2006). Mainstream production renders better photosynthesis efficiencies in terms of increased biomass yield on expense of lower cultivation efficiencies because of high energy input triggered by mineral fertilisers and chemicals. Due to photosynthesis' low efficiency, even a double biomass yield improves the overall efficiency only marginally. Vice versa, 20 to $56 \%$ lower energy input in organic crop production (Mäder et al. 2002) increases only marginally the overall efficiency.

By comparison, the efficiency of a photovoltaic collector is 165 to 248 -fold better than the conversion efficiency of biomass or biogas produced from rapeseed and rape straw into electric power. The efficiency of the thermal collector exceeds heat production from burning the rape crop 157 to 443 -fold. However, storage and continuous production of power and heat from sun energy is very limited. For that reason, the storage of sun energy in liquid carbon hydrates is subject of present research. Future biotechnology produces hydrogen and liquid carbon hydrates by $\mathrm{CO}_{2}$ and $\mathrm{H}_{2} \mathrm{O}$ (Centi et al. 2006, Gattrell et al. 2007) or thermo-chemical processes (Abu-Hamed et al. 2007, Jeong et al. 2007) powered by sun energy.

Finnish farmers own 6.6 million ha land or $19 \%$ of the countries area (Lampinen \& Jokinen 2006). A mean photosynthesis efficiency of $5 \%$ results in an energy crop potential of $44.8 \mathrm{MWh}$ per ha and year. Present thermal solar technique operating at $50 \%$ overall efficiency occupies only $1 \%$ of this area to cover the fossil energy consumption in Finland of $45.7 \mathrm{MWh}$ per ha and year (Nyholm et al. 2005). Other technologies show also clear advantages in respect of area required and cost of production compared to energy crops (Pimentel et al. 1994). Table 2 shows that electric power produced from energy crops may never be competitive with other energy technologies.

Table 2. Land resource requirements and total energy inputs for construction of solar and other energy facilities that produce 1 TWh year ${ }^{-1}$ of electricity. (Pimentel et al. 1994 modified). 1994: $1 \$=5,2295$ FIM, index 1376. 2007: 1 $\mathrm{EUR}=5.94573$ FIM, index 1677 .

\begin{tabular}{|c|c|c|c|c|c|}
\hline $\begin{array}{c}\text { Electrical energy } \\
\text { technology }\end{array}$ & $\begin{array}{c}\text { Land } \\
\text { required } \\
\text { ha }\end{array}$ & $\begin{array}{c}\text { Energy } \\
\text { required } \\
\text { GWh year }^{-1}\end{array}$ & $\begin{array}{c}\text { Energy return } \\
\text { on invest- } \\
\text { ment }\end{array}$ & $\begin{array}{c}\text { Energy return } \\
\text { on area } \\
\text { MWh ha }^{-1} \text { year }^{-1}\end{array}$ & $\begin{array}{c}\text { Cost } \\
€ \mathrm{MWh}^{-1}\end{array}$ \\
\hline Hydroelectric & 75000 & 21 & $48: 1$ & 13.4 & 21 \\
\hline Biomass & 220000 & 300 & $3: 1$ & 4.5 & $75-107$ \\
\hline Central receivers & 1100 & 100 & $10: 1$ & 909.1 & 107 \\
\hline Solar ponds & 5200 & 248 & $4: 1$ & 192.3 & 150 \\
\hline Wind power & 11666 & 205 & $5: 1$ & 85.7 & 64 \\
\hline Photovoltaics & 2700 & 108 & $9: 1$ & 370.4 & 321 \\
\hline Coal & 363 & 120 & $8: 1$ & 2754.8 & 32 \\
\hline Nuclear & 48 & 200 & $5: 1$ & 20833.3 & 54 \\
\hline
\end{tabular}

\section{Conclusion:}

Energy crop production is captivating with many win-win situations: environmentally neutral bio-fuels replace polluting fossil fuels, farmers get better prices for energy crops, the agrochemical industry gains from intensification of energy crop production, and turn over of power industry grows due to increasing energy consumption to produce agrochemicals and to process biomass into fuel. As a following, the state tax income improves too. However, better prices for mainstream energy crops may trigger export of environmental pollution at the expense of food production because higher overall efficiency in tropical coun- 
tries favours the import of organic raw material for bio fuel production.

Yet, high process efficiencies of technical processes to convert biomass into fuel justify the production of renewable energy from organic waste and residues. Thus, agriculture policy should not focus on energy crop production but on production of high quality food environment-friendly. The overall efficiency of energy production from energy crops will never be competitive with solar techniques.

Solar collectors replace fossil fuels for heat production outside agriculture already now sustainably and more efficient. Research on solar-technical processes to produce liquid carbon hydrates from methane, carbon dioxide, and water powered by solar energy without diversion into photosynthesis offers much a greater potential than research on energy crop production.

A measure for sustainability of renewable energy production is the energy surplus from sun energy conversion per capita and square meter of the nations land area. The production of renewable energy based on both photosynthesis and solar techniques is sustainable only if the energy consumption is below the product of yearly insolation and overall conversion efficiency. i.e. $<52.2 \mathrm{GWh}$ capita ${ }^{-1} \mathrm{a}^{-1}\left(897 \mathrm{kWh} \mathrm{m}^{-2} \mathrm{a}^{-}\right.$ $\left.{ }^{1} * 304472 \mathrm{~km}^{2} * 5236611 \mathrm{capita}^{-1}\right)$. In Finland, the land area is limited to $5.81 \mathrm{ha} \mathrm{capita}^{-1}$. Consequently, the sustainable energy consumption with overall conversion efficiency of e.g. $1 \%$ is limited to 57.9 MWh per resident and year. In 2006, the total energy consumption in Finland was 78.5 MWh per resident and year (Kauppa- ja teollisuusministeriö 2007).

Consequently, humankind has two ways only to warrant sustainable energy supply for the future: The first challenge is to increase of the overall efficiency of techniques to convert sun energy into fuel and electric power by means of improved process efficiencies. Probably cheaper and more rapidly to achieve, is the second way: energy saving.

One kernel of grain or oil seed has the potential to generate up to 50 kernels and more cultivated on fertile land. No hedge fond guarantees a similar interest rate. That means the entropy of seed is very low, compared to the thermal energy content. Thus, why humankind should burn its food?

\section{References}

Abu-Hamed T., Karni J., Epstein M. 2007. The use of boron for thermochemical storage and distribution of solar energy. Solar Energy 81: 93-101.

Bastianoni S., Facchini A., Susani L., Tiezzi, E. 2007. Emergy as a function of exergy. Energy 32: 1158-1162.

Centi G., Perathoner S. 2006. Converting $\mathrm{CO}_{2}$ to fuel: A dream or a challenge? The 232nd ACS National Meeting, San Francisco, CA, September 10-14, 2006, http://oasys2.confex.com/acs/232nm/techprogram/P990579.htm (12.01.2007).

Ekbladh, G.; Grönlund, E.; Ingemarson, F.; Karlsson, L.; Nilsson, S. and Strid Eriksson, I. Doherty, S. and Rydberg, T., Eds. 2002. Ecosystem properties and principles of living systems as foundation for sustainable agriculture - Critical reviews of environmental assessment tools, key findings and questions from a course process. Ecological Agriculture - 32, Centre for Sustainable Agriculture, Swedish University of Agricultural Sciences, Uppsala, 84 p.

Elsayed M., Matthews R., Mortimer N. 2003. Carbon and energy balances for a range of biofuels options. Project report number B/B6/00784/REP, Department of Trade and Industry Sustainable Energy Programme URN, 03/836, Resources Research Unit, Sheffield Hallam University, United Kingdom. Final Report for the Energy Technology Support Unit. Report No. 21/3, 27 p. http://oasys2.confex.com/acs/232nm/techprogram/P990579.htm (12.01.2007).

Bugge J. 2000. Note: Rapeseed oil for transport 1: energy balance and $\mathrm{CO}_{2}$ balance. The Danish Energy Agency's Model for Economic And Environmental Assessment Of Biofuels, DK-7760 Hurup Thy, http://oasys2.confex.com/acs/232nm/techprogram/P990579.htm (12.1.2007).

Gattrell M., Gupta N., Co A. 2007. Electrochemical reduction of CO2 to hydrocarbons to store renewable electrical energy and upgrade biogas. Energy Conversion and Management 48:1255-1265.

van Horn H., Wilkie A., Powers W., Nordstedt R. 1994. Components of dairy manure management systems. J. Dairy Sci. 77: 2008-2030.

Tae-Young Jeong, Gi-Cheol Cha, Ik-Keun Yoo and Dong-Jin Kim 2007. Hydrogen production from waste activated sludge by using separation membrane acid fermentation reactor and photosynthetic reactor. International Journal of Hydrogen Energy, 32: 525-530. 
Jiang M.M., Chen B., Zhou, J.B. Tao F.R., Li Z., Yang Z.F., Chen G.Q. 2007. Emergy account for biomass resource exploitation by agriculture in China. Energy Policy 35: 4704-4719.

Kauppa- ja teollisuusministeriö, 2007. Energiakatsaus 2/2007, 39s.

Knapp E., Jester T. 2000. An empirical perspective on the energy payback time for photovoltaic modules. American Solar Energy Society Solar 2000 Conference, Madison, Wisconsin June 16-21, 2000, http://oasys2.confex.com/acs/232nm/techprogram/P990579.htm (12.01.2007).

Lampinen A. Jokinen E. 2006. Suomen maatilojen energiatuotantopotentiaalit. University of Jyväskylä, bio- ja ympäristötieteiden laitos. Research reports in biological and environmental sciences 84: 1-160.

Mäder P., Fließach A., Dubois D., Gunst L. Fried P., Niggli U. 2002. Soil fertility and biodiversity in organic farming. Science 296: 1694-1697.

Nyholm, A. Risku-Norja H., Kapuinen P. 2005. Maaseudun uusiutuvien energiamuotojen kartoitus. MTT:n selvityksiä 89: 1-35.

Odum, H.T. 1996. Environmental Accounting, Emergy and Decision Making. John Wiley, NY, 370 pp.

Patzek T. 2004. Thermodynamics of the corn-ethanol biofuel cycle. Critical Reviews in Plant Sciences 23: 519-567.

Pimentel, D., Rodrigues, Wang T., Abrams R., Goldberg K., Staecker H., Ma E., Brueckner L., Trovato L., Chow C., Govindarajulu U., Boerke S. 1994. Renewable Energy: Economic and Environmental Issues. BioScience, 44: 536-547.

Ukidwe N.U., Bakshi B.R. 2007. Industrial and ecological cumulative exergy consumption of the United States via the 1997 input-output benchmark model. Energy 32: 1560-1592.

Schäfer W., Luomi, V. Palva, T. Parmala, S. Ahokas, J. 1986. Kasviöljyt dieselmoottorin polttoaineena. VAKOLAn tutkimusselostus 42:1-37.

SFS-EN ISO 14040 Ympäristöasioiden hallinta. Elinkaariarviointi. Periaatteet ja pääpiirteet Environmental management. Life cycle assessment. Principles and framework (ISO 14040:2006) 49 s. 